\title{
Siniša Mišić
}

Professor, Department of History

Filozofski fakultet, Univerzitet u Beogradu

Čika Ljubina 18 - 20, 11000 Beograd, Srbija

simisic@f.bg.ac.rs

\section{THE USAGE OF WATER IN PERSONAL HYGIENE IN MEDIEVAL SERBIA*}

\begin{abstract}
The aim of this paper is to show the history of personal hygiene in medieval Serbia. The everyday use of water in personal hygiene (washing of one's face, hands and feet, bathing, laundry) is documented in medical writings, archaeological findings and visual art. There is a suppression of public baths during the Middle Ages, but the emergence of private baths is evident, along with arrangement of spas (public baths) at thermal sources.
\end{abstract}

Keywords: water, hygiene, health resorts, Serbia

Non MeSH: bathing, Middle Ages, washing

The usage of freshwater in private life is manifold. The water for washing, drink and bathing was brought into the house in various cups and jugs. Female members of the household were responsible for the water supply as well as the laundry, which was performed at rivers and streams. In the city of Kotor, the laundry was performed

* The Ministry of Education, Science and Technology of Serbia supported this study on the basis of contract No. 177010. 
on the river Škudra. [1] Water was drunk from cups and goblets, and for its supply the pitchers and jugs were used, among which different types of kondirs (type of jug - large and small), ewers and badracs (type of pitcher) are discerned. [2,3] Medieval artists have accurately presented cups and chalices, especially when painting the „Wedding at Cana“. [4] The water was brought from springs and wells. Public wells in city squares and villages were commonplace in medieval Serbian lands. Wells also existed in all forts, cities and palaces. Particular courts had sanitary facilities, which made residence more comfortable. In that aspect the palaces in Golubac, Smederevo, Peć and Belgrade stand out. [5] However, in many Serbian cities, waterworks were non existent, and those available were neglected and poorly maintained (Skoplje, Zemun). In whole of Europe, and on Balkans as well, bad hygiene and usage of stagnant water have caused various diseases among population, and the malaria and all types of typhoid fevers were rampant. In accordance with existing conceptions, the most dreaded disease of the era - the plague - was caused by unhealthy air, which is in turn generated by decomposing corpses and water. [6] Because of all that, the effort to secure quality drinking water is evident, especially among higher echelons of society.

The running and spring waters played very important role for hygiene of medieval people. Everyone was washing his or hers face at least once daily, and the aristocracy washed its hands before and after meals, especially if the food was consumed with fingers. In the West, every meal was preceded and completed with the washing of the hands. [3] While washing hands, the servant poured water from a jug and simultaneously held an oval-shaped vessel in which water from washing was collected. This manner of washing of the hands is shown in the church of Staro Nagoričane (1317) in the scene "Pilate washes his hands". [7] The medieval artist presented there the familiar scene from everyday life. Unfortunately, we have no data on the subordinated populace, but it can be assumed that they kept the basic hygiene, out of the fear of disease and under church influence. One couldn't enter church while being dirty and unwashed, and the religious life demanded church presence at least on Sunday.

Unlike ancient Rome and its famous thermae, bathing in Middle Ages was usually conducted in sleeping chambers or bedrooms. Besides hand washing, our sources depict the scenes of washing of the feet. Medieval painter of Staro Nagoričane has shown realistic act and vessel in the scene "Washing of the feet." The vessel presented is round, somewhat deeper, with pedestal and short pole. [7] Because bathing 
withdraws into private sphere, public baths fall under regulations and scrutiny, and wealthier classes build their own private baths. Metropolitan of Nicaea, Alexander, complained during his imprisonment that he missed comfort and privacy of bath. [8] Roman baths continued to exist for some time, but they were increasingly dedicated to the ill. For bathing outside one's house, rivers and pools in spas remained. Medieval Serbia was rich in operational thermal sources (spas of Priboj and Mitrovica). Some of them (Gamzigrad) were used during the antiquity. In charter of the monastery of St. George near the city of Skoplje, the cultivated field and spa was mentioned. [9] It is obvious that a thermal source was meant. It represents special value; therefore it's mentioned in the charter.

Under the church influence begins, from $8^{\text {th }}$ century on, restraint from frequent bathing. In $12^{\text {th }}$ century Byzantium bathing three times a week was considered excessive. [10] The calendars prescribed three to eight baths per month, depending on a season. In scriptures on hygiene, which were present in medieval Serbia, more frequent bathing in June was prescribed, along with perfusion of feet with cold water, but one should keep away from cold water in August. Bathing is advised in November, but not in December, while in January more frequent baths are recommended. [6] It is probable that these guidelines were followed by literate people and their surroundings, and that part of the commoners looked up to them, at least to some extent.

With the arrival of Byzantine princesses on Serbian court, at first Eudocia, the wife of Stefan Nemanjić, then Anna, the wife of King Radoslav, and subsequently Simonide in 1299, the wife of King Milutin, the strong influence of Byzantium was exerted on everyday life of court and nobility. It may be concluded that this influence was visible in this sphere of life as well. The bathing tubs and baths are so common at the end of Middle Ages in the West, that there's no more restraint from frequent body washing. Bathing was conducted in bedroom or steam bath. In Serbia, bathing is conducted in bedrooms too, and it seems that, according to the archaeological research, rooms with devices for heating water were nonexistent. Sauna becomes widespread custom in both Germanic and Slavic worlds. In 1416 the city of Baden had around 30 public baths. [11] Our sources are silent regarding the question of public baths in Serbia. They had to exist, at least in spas that were used for medicinal purposes. In the charter of the monastery of St. George near the city of Skoplje, it is ruled that one quarter of the water from river Slivštica was to be used by the monastery and its spa. [9] It is obvious that the bath was meant, and 
because this regulation existed before King Milutin (1300), probably the bath (spa) itself was from previous, Byzantine times. It continued to operate after the arrival of Serbian rule.

It is necessary to emphasize that frescoes of Serbian medieval rulers and aristocrats (King Milutin, Emperor Dušan, Despot Stefan Lazarević, Despot Jovan Oliver, and Vlatko Paskačić) give the impression of men with well kept long hairs and beards, which demanded orderly washing and general body care. The image of "dirty and greasy" medieval nobleman and commoner is stereotype that in general doesn't correspond with historical facts. [3]

The circumstantial evidence on personal hygiene is found in medical scriptures. Thus the cause given for disorder of the digestive system is, among others, that many people bathe, but without adequate facilities. The treatment envisages bathing in mild water. [12] This is the indirect mention of medieval bathing habits, which indicates that a lot of people took care of their personal hygiene. Also, small children had to be bathed regularly. Medieval painters displayed bathing of an infant in the cycle of "Birth" of Jesus or Virgin Mary. The representation of this scene shows us how this action was performed. The children were bathed in a vessel which looked very much like baptistery. It is a round, deep vessel with pedestal and pole. It was made from metal or marble. While one woman pours water from the pitcher, the other one holds the child, while trying the temperature of the water with her right hand. This scene is beautifully presented on the frescoes "The Birth of Virgin Mary" in the church of St. Ahilije in Arilje (1296) and in the King's church in Studenica (1313/1314), as well as on the fresco "The Birth of Christ" in the monastery Sopoćani, on the northern wall under the dome. $[7,13]$ There the painter depicted the world and objects of his time. The inhabitants of villages and katuns (pastures) were bathing in rivers and streams, or at the house in barrels, tubs or troughs. In cities, personal hygiene was more developed, especially where large colonies of merchants from Dubrovnik were present (Prizren, Novo Brdo, Beograd, Smederevo).

In Serbian medieval medical texts, recommended treatment for certain diseases (fevers) was bath in the mild water. Certain types of remedies for particular disease (liver) should be drunk while bathing - "in the spa". [6] The term itself refers to a special room (spa - bath), and not to the bathing in a tub or in a barrel. It can be seen from the medical codex of Hilandar that the medieval writer made distinction 
between this two types of bath. According to this codex, the treatment for the fever required, among other things, that the patient bathes first "in the barrel, and not in the spa", and that the water is not very warm. During this procedure, the patient should wash his or hers hands and face with rosewater. [14] It is clear that this document recommends bathing in a barrel and not in the bathroom (bathtub). In wealthier houses, especially in cities, special premises for bathing could exist - "the spa". Specially arranged bathroom has not been corroborated in the archaeologically surveyed palaces in medieval Serbia.

\section{References:}

1) Живковић Т. Црквена организација у српским земљама: (рани средњи век) [The church organization in Serbian lands]. Београд; 2004.

2) Бикић В. Кухиња и трпеза: посуђе у свакодневном животу [The kitchen and the table: dishes in everyday life]. In: Марјановић-Душанић C, Поповић Д, editors. Приватни живот у српским земљама средњег века. Београд; 2004. 51-66.

3) Мишић С. Коришћење унутрашњих вода у српским земљама средњег века [The usage of internal waters in Serbian medieval lands]. Београд; 2007.

4) Тодић Б. Грачаница - сликарство [Gračanica - The painting]. Београд; 1988.

5) Милошевић Г. Становање у средњовековној Србији [The housing in medieval Serbia]. Београд; 1997.

6) Катић Р. Српска средњовековна медицина [The Serbian medieval medicine]. Горњи Милановац; 1990.

7) Радојчић С. Старо српско сликарство [The old Serbian painting].Београд; 1966.

8) Аријес Ф, Диби Ж, editors. Историја приватног живота [The history of private life] 1. Од Римског царства до 1000. gодине. Београд; 2000.

9) Илиевска К, Мошин BA, editors. Споменици за средновековната и поновата историја на Македонија [The monuments of medieval and modern history of Macedonia] 1, Скопје; 1975. 
10) Breje L. Vizantijska civilizacija [The Byzantine civilization]. Beograd; 1976.

11) Аријес $Ф$, Диби Ж, editors. Историја приватног живота [The history of private life] 2. Од феудалне Европе до Ренесансе. Београд; 2001.

12) Лазић М, Котарчић Љ, editors. Средњовековни медицински списи [The medieval medical writings]. Стара српска књижевност 24. Београд; 1988 .

13) Ђурић ВЈ. Сопоћани [Sopoćani]. Београд; 1991.

14) Трифуновић Ђ. Чуло мириса код старих српских писаца [The sense of smell of old Serbian writers]. Блгария и Србия в контекста на византийската цивилизация. София; 2005. 